
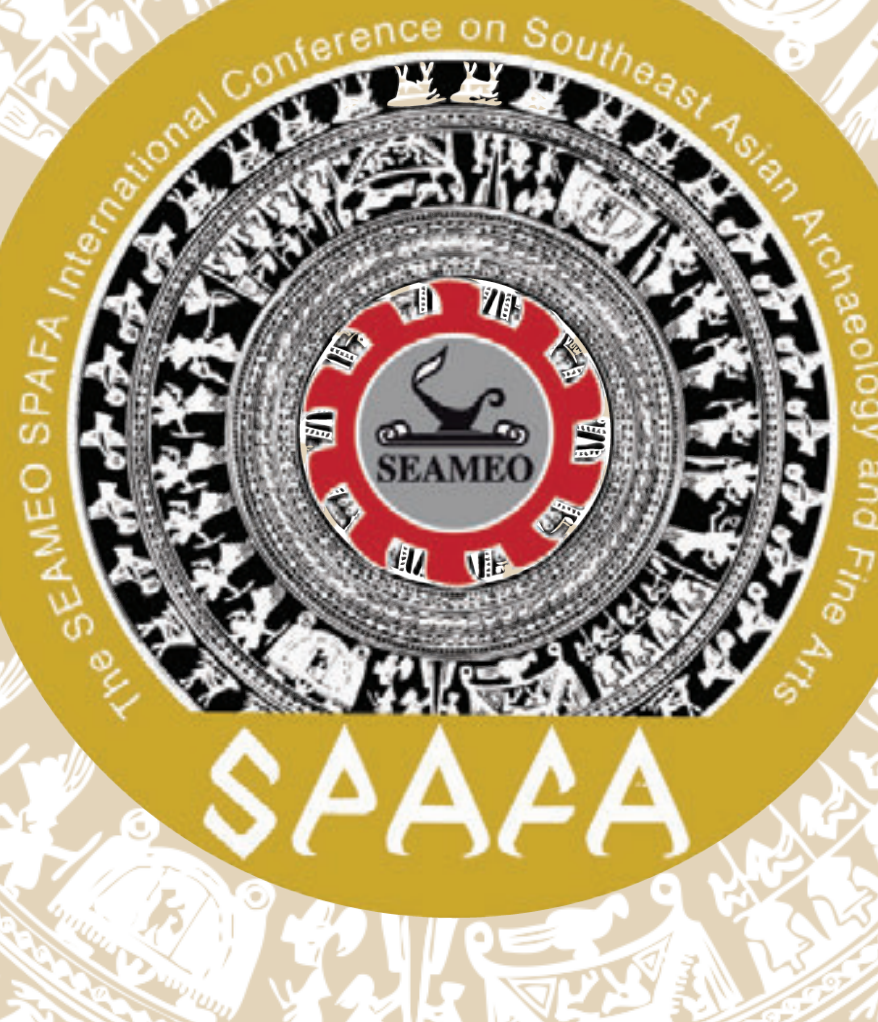
SPAFACON2021 is published by SEAMEO SPAFA, the Regional Centre for Archaeology and Fine Arts established by the Southeast Asian Ministers of Education Organization. SEAMEO SPAFA focusses on archaeology and fine arts in Southeast Asia, and promotes awareness and appreciation of the cultural heritage of the region. Its member-countries are Brunei, Cambodia, Indonesia, Lao PDR, Malaysia, Myanmar, the Philippines, Singapore, Thailand, Timor-Leste, and Vietnam; and its associate member-countries are Australia, Canada, France, Germany, the Netherlands, New Zealand, Spain and the United Kingdom. 


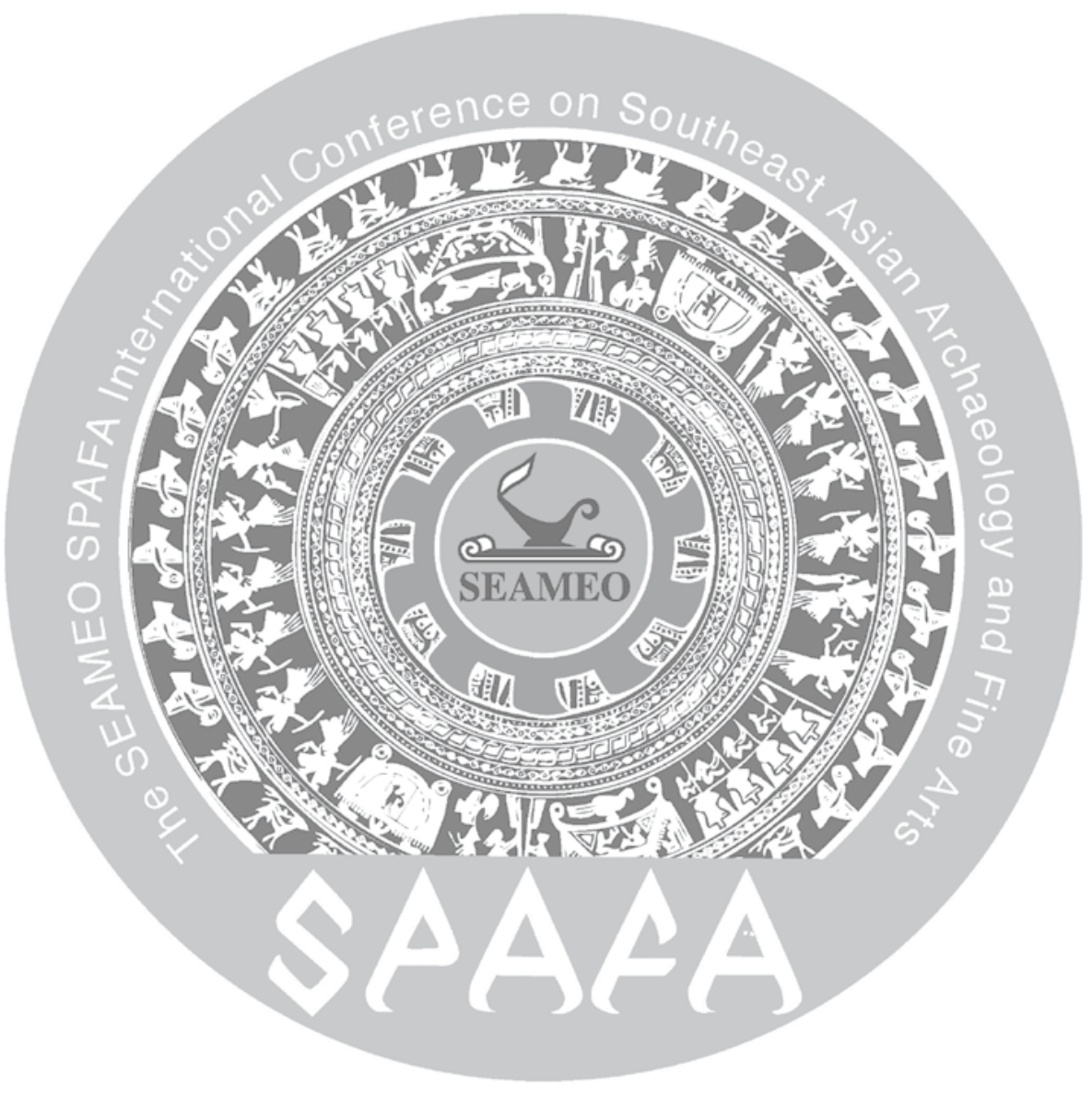

SPAFACON2021

Papers from the SEAMEO SPAFA International Conference on SOUTHEAST ASIAN ARCHAEOLOGY AND FINE ARTS

13 - 17 December 2021

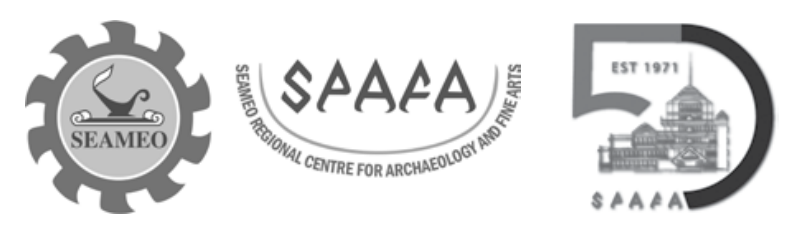


2021 SEAMEO SPAFA

ISBN: 978-616-7961-55-2

ISBN (e-book): 978-616-7961-54-5

DOI 10.26721/spafa.pqcnu8815a

\section{Publisher}

SEAMEO SPAFA Regional Centre for Archaeology and Fine Arts

81/1 Sri Ayutthaya Road, Dusit

Bangkok 10300, Thailand

Tel: +66 (0) 22804022 to 9

Fax: +66 (0) 22804030

www.seameo-spafa.org

E-mail: spafa@seameo-spafa.org

\section{Editor}

Dr Noel Hidalgo Tan

\section{Organizing Committee}

Mrs Somlak Charoenpot

Ms Vassana Kerdsupap

Mr Kanal Khiev

Mr Ean Lee

Ms Gabrielle Anne Mangaser

Dr Hatthaya Siriphatthanakun

Ms Ratchaporn Tesjeeb

Mr Patrick Xia Linhao

Dr Noel Hidalgo Tan

\section{(c) (1) (2)}

Copyright in the volume as a whole is vested in SEAMEO SPAFA, and copyright in the individual chapters also belong to their respective authors and licensed under Creative Commons CC BY-SA 4.0. To view a copy of this license, visit https://creativecommons. org/licenses/by-sa/4.0/

The papers in this publication have not been peer-reviewed and may thus contain preliminary findings, errors, or information that has yet to be endorsed by the relevant academic community. The views expressed in the publication do not necessarily reflect the opinions or policies of SEAMEO SPAFA. 


\section{Title}

\section{CONTENT}

\begin{tabular}{|c|c|c|}
\hline Title & Author & Page \\
\hline \multicolumn{3}{|l|}{ Introduction } \\
\hline $\begin{array}{l}\text { A Historiography of Settlement Archaeology in Southeast } \\
\text { Asia, with Emphasis on the Pre-industrial State Formations }\end{array}$ & Gyles Iannone & 1 \\
\hline $\begin{array}{l}\text { Ocean Imperatives: analysing shipping infrastructure for the } \\
\text { study of maritime networks in Southeast Asia }\end{array}$ & Veronica Walker Vadillo & 17 \\
\hline $\begin{array}{l}\text { Forms of government and local community participation in } \\
\text { the management of cultural World Heritage sites in Southeast } \\
\text { Asia }\end{array}$ & Vithaya Arporn & 24 \\
\hline $\begin{array}{l}\text { Cultural interaction between Việt Nam and Southeast Asian } \\
\text { nations in the } 15^{\text {th }}-16^{\text {th }} \text { centuries: An overview of pottery } \\
\text { items from ancient shipwrecks on display at the Museum of } \\
\text { History in Hồ Chí Minh City }\end{array}$ & $\begin{array}{l}\text { Phạm Ngọc Uyên, } \\
\text { Nguyễn Thị Tú Anh }\end{array}$ & 29 \\
\hline $\begin{array}{l}\text { Sequential Least-Cost Path Sailing Model for Early } 17^{\text {th }} \\
\text { Century South China Sea: Digitally Navigating the Selden } \\
\text { Map of China }\end{array}$ & Wesa Perttola & 40 \\
\hline $\begin{array}{l}\text { The Prevailing Art and Tradition of Intentional Dental } \\
\text { Modification in Prehistoric Southeast Asia }\end{array}$ & Maria Kathryn N. Purnell & 56 \\
\hline $\begin{array}{l}\text { The Still Unexplored Parts of Southeast Asian Archaeology: } \\
\text { Colonial Archaeology Singapore }\end{array}$ & Sxuann Sim & 74 \\
\hline $\begin{array}{l}\text { Khao San Dam: The Archaeological Evidence of Burnt Rice } \\
\text { Festival in Southern Thailand }\end{array}$ & Pakpadee Yukongdi & 83 \\
\hline $\begin{array}{l}\text { Before Bagan: Using Archaeological Data Sets to Assess the } \\
\text { Traditional Historical Narrative }\end{array}$ & $\begin{array}{l}\text { Scott Macrae, Gyles } \\
\text { Iannone, Kong Cheong, } \\
\text { Pyiet Phyo Kyaw }\end{array}$ & 96 \\
\hline The Rock Art in Kinta Valley, West Malaysia: A synthesis & $\begin{array}{l}\text { Chaw Yeh Saw } \\
\text { Hsiao Mei Goh }\end{array}$ & 114 \\
\hline $\begin{array}{l}\text { New Archaeological Discoveries: Gates and Turrets of } 16^{\text {th }} \\
\text { Burmese Royal Capital of Hamsāvatī }\end{array}$ & Thaw Zin Latt & 131 \\
\hline $\begin{array}{l}\text { A preliminary survey of Chinese ceramics in Champa } \\
\text { archaeological sites }\end{array}$ & Do Truong Giang & 148 \\
\hline $\begin{array}{l}\text { A Study on the Structure and Significance of the North } \\
\text { Sanctuary at Western Prasat Top }\end{array}$ & $\begin{array}{l}\text { SATO Yuni, TAMURA } \\
\text { Tomomi, SUGIYAMA } \\
\text { Hiroshi, LAM Sopheak, } \\
\text { SOK Keo Sovannara, } \\
\text { LOEUNG Ravattey, ROS } \\
\text { Visoth }\end{array}$ & 166 \\
\hline The funeral cave of Laang Spean & $\begin{array}{l}\text { Valéry Zeitoun, } \\
\text { Heng Sophady, Hubert } \\
\text { Forestier }\end{array}$ & 173 \\
\hline
\end{tabular}




\begin{tabular}{|c|c|c|}
\hline Title & Author & Page \\
\hline $\begin{array}{l}\text { The Bronze Age People of Ban Kao: A Preliminary Analysis } \\
\text { of the Human Remains from Ban Ta Po Archaeological Site, } \\
\text { Western Thailand }\end{array}$ & $\begin{array}{l}\text { Naruphol } \\
\text { Wangthongchaicharoen, } \\
\text { Supamas Duangsakul, } \\
\text { Pira Venunan, Sukanya } \\
\text { Lertwinitnun, Siriyupon } \\
\text { Tubpenthai }\end{array}$ & 187 \\
\hline The Mt. Popa Watershed and Bagan's Bronze-Iron Age & Elizabeth Moore & 195 \\
\hline $\begin{array}{l}\text { After } 30 \text { Years and During a Pandemic: Pottery Production } \\
\text { and Distribution in Bagacay, Talibon in the Island of Bohol in } \\
\text { the Philippines }\end{array}$ & $\begin{array}{l}\text { Rhayan Gatbonton } \\
\text { Melendres }\end{array}$ & 205 \\
\hline $\begin{array}{l}\text { Heritage Education in Myanmar - developing resilience and } \\
\text { sustainability through community engagement }\end{array}$ & $\begin{array}{l}\text { Su Su, Win Thant Win } \\
\text { Shwin, Ohnmar Myo, } \\
\text { Charlotte Galloway, } \\
\text { Elizabeth Moore }\end{array}$ & 220 \\
\hline $\begin{array}{l}\text { As my father said: Traditional boatbuilding in Pasuruan, East } \\
\text { Java }\end{array}$ & $\begin{array}{l}\text { Agni Mochtar, Putri } \\
\text { Taniardi, R. Ahmad } \\
\text { Ginanjar Purnawibawa }\end{array}$ & 234 \\
\hline $\begin{array}{l}\text { Tangibility-Intangibility on UNESCO World Heritage } \\
\text { Baroque Philippine Churches: the Spirit of Place and Its } \\
\text { Collective Memory }\end{array}$ & Hee Sook Lee-Niinioja & 241 \\
\hline $\begin{array}{l}\text { Myinkaba village Bagan: The Resilience of Traditional } \\
\text { Knowledge and Culture }\end{array}$ & Theint Aung & 254 \\
\hline $\begin{array}{l}\text { Thai Carpentry Knowledge Transmission: Development of } \\
\text { Traditional Apprenticeships in a New Context }\end{array}$ & Nichamon Hiranpruek & 262 \\
\hline $\begin{array}{l}\text { The Factors of Market Success and Failure of Contemporary } \\
\text { Artists from ASEAN countries }\end{array}$ & Dr Rémy JARRY & 268 \\
\hline $\begin{array}{l}\text { The Forgotten Women: Investigating the Absence of the } \\
\text { Female Artist from Traditionally Male-Centric Southeast } \\
\text { Asian Contemporary Art Historical Narratives }\end{array}$ & Vasanth Narayanan & 279 \\
\hline As One With Nature: Southeast Asian Aesthetic Expressions & Victor R. Savage & 289 \\
\hline $\begin{array}{l}\text { The Series Of Archaeological Dances: A Historical Study and } \\
\text { Dance Moves Recording With Labanotation }\end{array}$ & Dharakorn Chandnasaro & 309 \\
\hline $\begin{array}{l}\text { Musical Instruments on the 16th century bas reliefs in } \\
\text { the North Gallery-East Wing of Angkor Wat : Dating and } \\
\text { Significance }\end{array}$ & Arsenio Nicolas & 324 \\
\hline $\begin{array}{l}\text { Photography in Indonesian Archaeology of the } 19^{\text {th }} \text { to the } \\
\text { Early } 20^{\text {th }} \text { Century }\end{array}$ & $\begin{array}{l}\text { Ahmad Kholdun Ibnu } \\
\text { Sholah }\end{array}$ & 356 \\
\hline $\begin{array}{l}\text { Old Burmese weights were not opium weights. They were } \\
\text { weights. What else do we know about them? }\end{array}$ & Bob Hudson & 369 \\
\hline $\begin{array}{l}\text { Religious Object" Exhibition in the Context of Cultural } \\
\text { Change and Covid-19 Social Distancing (Case studies of } \\
\text { Khmer's Nagar boat in the South of Vietnam) }\end{array}$ & Phạm Thị Thủy Chung & 381 \\
\hline
\end{tabular}




\section{Title}

Author

Page

Creativity and Innovation in Cultural Heritage Management in Plunturan Village, Pulung District, Ponorogo Regency,

Ria Kusuma Wardani, S.Pd.

East Java Province of Indonesia Towards Tourism Village

Beyond the artefact : promoting technology

Cécile de Francquen 407

Indonesian Museum after New Order Regime: The

Representation that Never Disappears

Ayu Dipta Kirana, Fajar

Aji Jiwandono

Geological Museum Innovations to Dealing with Covid-19 Ifan Yoga Pratama Suharyogi, Agustina Djafar, Rahajeng Ayu

Pandemic 


\section{INTRODUCTION}

This volume contains the extended abstracts from the papers presented at the SEAMEO SPAFA International Conference on Southeast Asian Archaeology and Fine Arts, which was held online from 13 to 17 December 2021. Also known as the SPAFACON2021, this conference was organised online due to the pandemic. Despite the disruption brought about by Covid-19 to our in-person events, training programmes and field research, it is heartening to see that archaeology and cultural heritage has continued under new modes of communication and collaboration.

This fourth iteration of the SPAFACON is also scheduled a year earlier than our usual triennial cycle to commemorate the 50th anniversary of SEAMEO initiating a centre dedicated towards archaeology and the fine arts. Over the past year, SPAFA has also been highlighting this legacy of international cooperation and capacity-building by sharing our photographic archives on our social media.

I am delighted by the high level of enthusiasm and intellectual curiosity brought by the participants to the conference. During our call for papers we received close to 90 submissions, but owing to the pressures of time and the online format, we were only able to accept 34 papers for the conference. The variety of papers present here, although a small set compared with our usual proceedings, reflects the breadth of the centre's ambit covering not just archaeology, but also performing arts, visual arts, museum studies, and other aspects of Southeast Asian cultural heritage.

I would like to thank all the participants, without whom this conference would not be possible in its present form, in particular, our Governing Board members who represent every country in Southeast Asia, and to the Ministry of Culture, Thailand and the Ministry of Education, Thailand for their long-standing support of SEAMEO SPAFA and its activities.

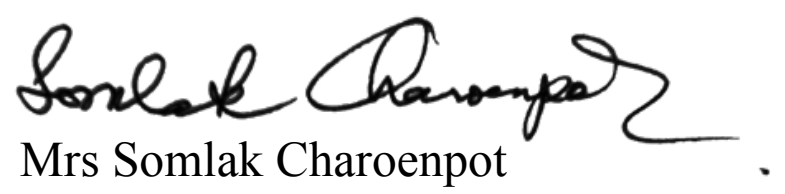

Centre Director

SEAMEO SPAFA 


\title{
Cultural interaction between Việt Nam and Southeast Asian nations in the 15th-16th centuries: An overview of pottery items from ancient shipwrecks on display at the Museum of History in Hồ Chí Minh City
}

\section{Giao lưu văn hóa giữa Việt Nam và các quốc gia Đông Nam Á: Tổng quan về loại hình gốm tàu đắm niên đại thế kỷ 15-16 đang được lưu giữ tại Bảo tàng Lịch sử Thành phố Hồ Chí Minh}

10792/pqcnu8815a-04

Phạm Ngọc Uyên and

Fine Arts Museum,

Ho Chi Minh City

\author{
Nguyễn Thị Tú Anh \\ Vietnam National University Ho Chi Minh City, \\ University of Social Sciences and Humanities
}

\section{Abstract}

This article systematizes the typical covered box ceramics after the excavation of the shipwrecks in Cham Islands, Hội An currently on display at the Museum of History in Hồ Chí Minh City. Comparisons lead to the assumption that such products can only satisfy the needs of the consumer market based on the iconographic interpretation accounting on traditional literature in Việt Nam and some Southeast Asian nations, such as Java, Malay, the Philippines. This article also assumes that it is a product ordered by foreign traders, or the creation of Vietnamese ceramic artists, because animals/other images that are shaped and decorated on pottery have so far not been fully accounted and researched in Vietnamese folk beliefs.

Tiểu luận này hệ thống lại loại hình hộp gốm có nắp và hoa văn tiêu biểu của các loại di vật này trong sưu tập tàu đắm Hội An, hiện đang trưng bày tại Bảo tàng Lịch sử Thành phố Hồ Chí Minh. Các so sánh và diễn giải tiếu tượng học đưa đến nhận định rằng các sản phẩm gốm đó có thể chỉ đáp ứng nhu cầu của thị trường tiêu thụ dựa trên những tài liệu thành văn và truyện cổ giữa Việt Nam và truyền thống một số các quốc gia Đông Nam Á, như Java, Malay, Philippines. Bài viết này cũng giả thiết rằng đó là sản phẩm được các thương nhân nước ngoài đặt hàng, hoặc, là sự sáng tạo của nghệ nhân gốm Việt Nam, bởi các con vật/các đề tài khác được tạo hình và trang trí trên các di vật này cho đến nay vẫn chưa được ghi nhận đầy đủ và nghiên cứu sâu trong tín ngưỡng dân gian Việt Nam.

\section{Keywords}

covered boxes; shipwrecks; maritime trade; Museum of History in Hồ Chí Minh City hộp có nắp; tàu đắm; thương mại biển; Bảo tàng Lịch sử Thành phố Hồ Chí Minh 


\section{Introduction}

At the Museum of History in Hồ Chí Minh City (MHiHCMC), the collection of Chu Đậu ceramic was built after the excavation of the shipwrecks in Cù Lao Chàm/Cham Islands conducted between 1997 and 1999. After that, 4362 ceramic artifacts were transferred to the museum in the year 2000. It is impressed by the variety of types and quantities, in which the types of covered box are outstanding. An estimated 1146 covered boxes all of which have been classified among them, regardless of its size and decoration.

This paper briefly introduces the Chu Đậu ceramics dating to the $15^{\text {th }}-16^{\text {th }}$ century on display at the MHiHCMC. The covered box ceramics will next be focused for discussion, its shapes and patterns will be examined and compared with those made by craftsmen from abroad at the same period. It may indicate the distinction between Vietnamese and foreign styles in this category. It may also reinforce the perception of the quality of Vietnamese ceramics. Vietnamese craftsmen were able to meet the consumption requirements of the international market, thereby showing the role of pottery in cultural exchanges between Việt Nam and foreign countries in ancient times. Ceramics have bridged cultural exchanges between Việt Nam and other countries since ancient times.

\section{Some groups of outstanding blue-and-white ceramic boxes}

The group of blue-and-white covered boxes will first be selected for presentation with its lid having a zoomorphic knob (Figure 1).
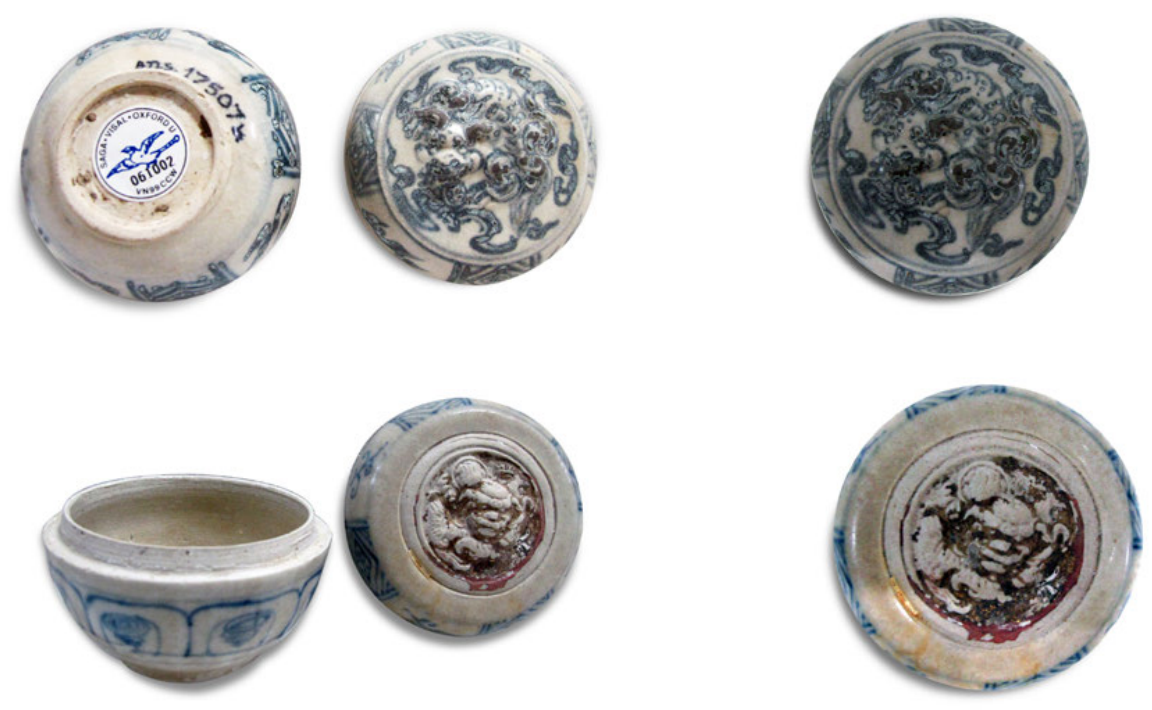

Fig. 1 The covered boxes representing a 'lion' image, on displaying at MHiHCMC. Photo: Phạm Ngọc Uyên 
In terms of shape, they have round and shallow form, decorating with six or eight vertical panels on the sides of lid and body, the lower body with upturned lotus panels enclosing leaf forms standing on a tall foot, the outer side of the foot rim with a chocolate slip with a translucent glaze, although there are some unglazed flat foot with a putty-colored biscuit. The knob-handles are represented by the 'lion image' as described in the excavation report ${ }^{1}$ (Ysaguirre et al. 2000) featured into two categories: 1/ a 'sitting lion' is raising its head; $2 /$ knob is molded in the form of a 'lion' and raised on the flat lid. The image of 'lion' may be called 'Qilin' in Chinese art, recently found in bulk in Java and the Philippines (Njoto 2018: 52; Barretto-Tesoro 2020:13).

A stone 'lion-dog' figure, called 'Nghê' in Vietnamese, is a popular mythical guardian animal in various northern Vietnamese sanctuaries, Louis Berzacier (1955: 193-194, fig. 33) sketched and discussed in detail to reach a conclusion that it dates back to the $11^{\text {th }}$ century, though its origins in Vietnamese culture is still uncertain. In addition, the 'lion' figure is still accounted as a feature of Chinese art mentioned in some of Vietnamese publications today (Lý Lược Tam, Huỳnh Ngọc Trảng 1996: 148-150).

John Guy (2005: 107-111) briefly summarizes that the Vietnamese glazed wares on those wrecks came from the north, and served the market in insular Southeast Asia, dating from the late $15^{\text {th }}$ to the early $16^{\text {th }}$ century; of which Java was the largest single market for such items. It may indicate that those blue-and-white must be ordered and responsive to the customer culture in the consumer market. Therefore, the term 'lion' should be referred to as its name by consumers in Java.

Hélène Njoto (2018) has recently employed a feline-like figure as an example for her presentation about the early Javanese Muslim elite's taste for Vietnamese and Sinitic culture in the $15^{\text {th }}-17^{\text {th }}$ century. Comparisons were taking her to recognize that the feline image in Pasisir is the result of the exchanges between Java, China, and Vietnamese coasts. It should be emphasized that the Muslims gradually adopted Javanese culture while the Javanese slowly converted to Islam at that time (Njoto 2018: 42). That is why feline figures combining Vietnamese or Sinitic features were adorned in palaces, mosques, and mausoleums of the elite in early Islamic Pasisir period in Java. Marie-France Dupoizat (2013) indicates that blue-and-white Vietnamese wares were the most frequently exported to the Malay world in the $15^{\text {th }}$ century.

1 A description from 'Report on underwater archaeology and archaeological excavations in Cham Island in 1997-1999', p.73. 
The above ideas may also indicate that the knob-handles representing an 'lion' figure were satisfying the needs of the elite not only in Java but also in the Malay world, as a hallmark of the new generation of Muslim elites at the time (Njoto 2018: 58).
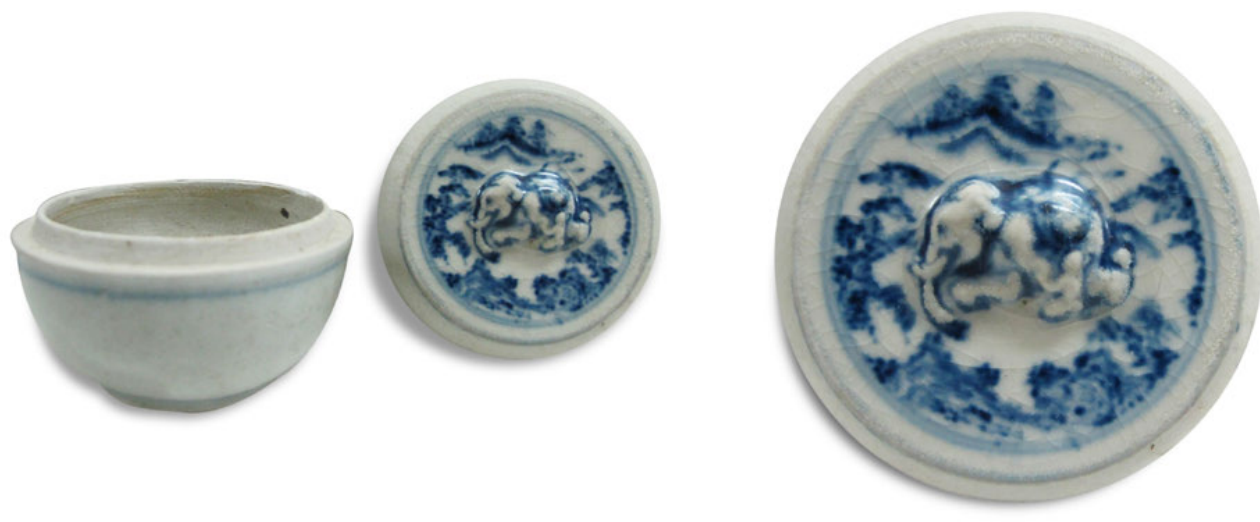

Fig. 2 The covered box representing an 'elephant' image, on displaying at MHiHCMC. Photo: Phạm Ngọc Uyên.

The shaped elephant knob is another featured image of this type of lidded box. On average $6.4 \mathrm{~cm}$ in diameter each box has a round shape with an elephant is depicted in a standing or kneeling positions, with a trunk, big ears and a pair of ivory; the elephant image is raised on a flat lid, prominent against a background of landscape paintings, scrolls of clouds or 'ruyi' symbols (?), all set within a double line border displaying simple blue line, all rendered in underglaze blue against a creamy white ground while some of those further decorated in overglaze enamels.

Wan Norasikin Wan Ismail and colleagues (2016: 148-149) indicate that elephant is one of the animals mentioned as a symbol of power in Malay proverbs, in which 'Hikayat Merong Maha Wangsa' also known as the Kedah Annals examples, this Malay literary work account of the tales relating to the kingdom of Kedah. Particularly, 'Hikayat Rajaraja Pasai' is proposed as the earliest work of the first Malay-Muslim kingdom perhaps compiled in the year 1390 (Nicolas 2017: 3). In Malay proverbs, the trunk of an elephant becomes a multifunctional hand to pull the trees, bring food and water to its mouth, hence elephant is symbolized as strength, representing power and highly-positioned, wealth and luxury, associated the Malay value system (Wan Norasikin Wan Ismail et al. 2016: 150). 
In Khmer art, the elephant image was depicted in Angkor architectures under the reign of Jayavarman VII, dating back to the first half of $12^{\text {th }}$ century (Rooney 2008: 11). Meanwhile, the white elephant symbolizes supreme kingship during the period of King Ramkhamhaeng of the Sukhothai dynasty in the $13^{\text {th }}$ century; elephants continue to be recognized as a symbol in the Thai royal family under the reign of the King Mahachakkaphat in the $16^{\text {th }}$ century (Jianghua Han 2019: 155).

Kenneth Hall (1985: 250-251) indicates that the power of the Majapahit empire reached its height in the mid- $14^{\text {th }}$ century, and Java was one of the developed maritime states in early Southeast Asia in the $14^{\text {th }}$ through $16^{\text {th }}$ centuries, that Southeast Asian crafts partly reflect those characteristics.

Barbara Wagner (1980) indicates that design and organization of the covered boxes are similar between Annam and Sawankaloke products. John Shaw (1982: 25-26) noticed that there was no difference between the ceramic products of the kilns in Gò Sành and Sawankaloke, based on comparisons on samples from the Koh Khram sunken ship; Shaw therefore predicts that samples or drawings of the wares of one kiln to a rival kiln with a request for copies at a cheaper cost, whose business was carried out by the entrepreneurs engaged in the glazed pottery or their customers in Indonesia and the Philippines. Shaw also emphasized that not all new ideas for enamelwares come from China (Shaw 1982: ibid).

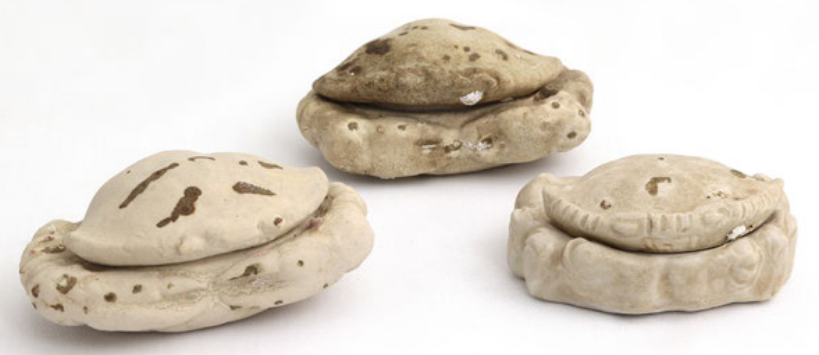

Fig. 3 Crab shaped box with lid, on displaying at MHiHCMC. Photo: Phạm Ngọc Uyên

Crab is also one of the crustaceans employed to shape boxes, with widths $7.7-10.2 \mathrm{~cm}$ (Figure 3), which is also quite common in pottery found on shipwrecks. The shell on the back of the crab, also called the carapace, can be lifted off the legs to reveal an interior compartment covered in translucent glaze (?).

In Vietnamese folklore, crab walking sideways represents personality, stubbornness example, so it has a common idiom called "ngang nhu cua" in Vietnamese but have no any mythological or moral significance associated with the crab figure; meanwhile, the four other animals are dragon, qilin, turtle, and phoenix which have long been popular in Vietnamese folk beliefs, known as the four sacred animals. 
Avelina Gil (1973: 26-27) mentions that 'Mayyang and the Crab' is one of the popular folktales in the Philippines, in which Mayyang figure represents the Cinderella image in the Philippines version, she was abused and bullied by her stepsisters and their mother even though she was the household drudge. The most distinctive is that Mayyang's mother is a sea creature, a huge crab, which turns out to be her mother in another form whenever she suffers or is in trouble (ibid.). In general, a crab or a fish is often a variation used for the fairy godmother in Filipino folklore (Gil 1973: 31; Eugenio 1985: 165).

The ideas above may explain how the ceramic that comes in the shape of a crab or fish can be ordered by merchants and probably served mainly in the ancient Philippines market, that is why they were found in several wrecks such as the Pandanan one.

In addition, the group of polygonal shapes is also a noteworthy product, average width of each $6 \mathrm{~cm}$, and diameter of each $13.6 \mathrm{~cm}$. A simple floral is painted in each flat top within a double line frame rendered in underglaze blue against a creamy white ground. They also designed a central floral medallion, from which radiate six to eight petal-shaped bands attached to the flower heads or sprayed leaves alternating with a trellis pattern.

The design of the polygon is mainly derived from a square which is why square structures are widely used in the Malay traditional woodcarving (Silah et al. 2013: 827) (Figure 4); it goes on to explain that the square is widely used in multiples of four, the square also represents for the earth, materiality and boundary between the internal and external world (ibid.).
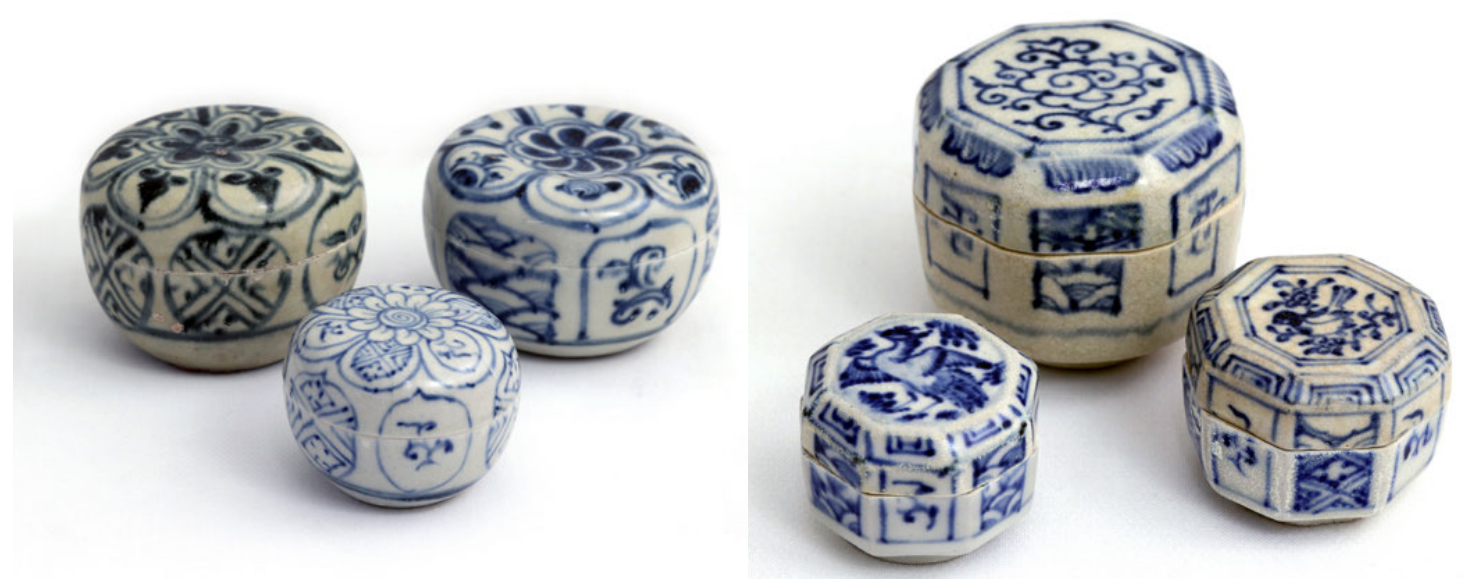

Figs. 4a-b. The covered boxes representing in polygonal shape, on displaying at MHiHCMC. Photo: Phạm Ngọc Uyên 
Furthermore, a group of round boxes decorated with floral patterns also occupy the relative number of the museum's collection (Figure 5). On average $6 \mathrm{~cm}$ in diameter each box has a round shape decorated to the top with an abstracted floral motif, all surrounded by a blue ring around the cover edge. The shape of the circle is associated with the concept of God in Malay art, the circle is 'the essence of Allah', the moon shape represents the 'heart', and the sun thus symbolizes the 'essence of God' (Silah et al. 2013: 827).

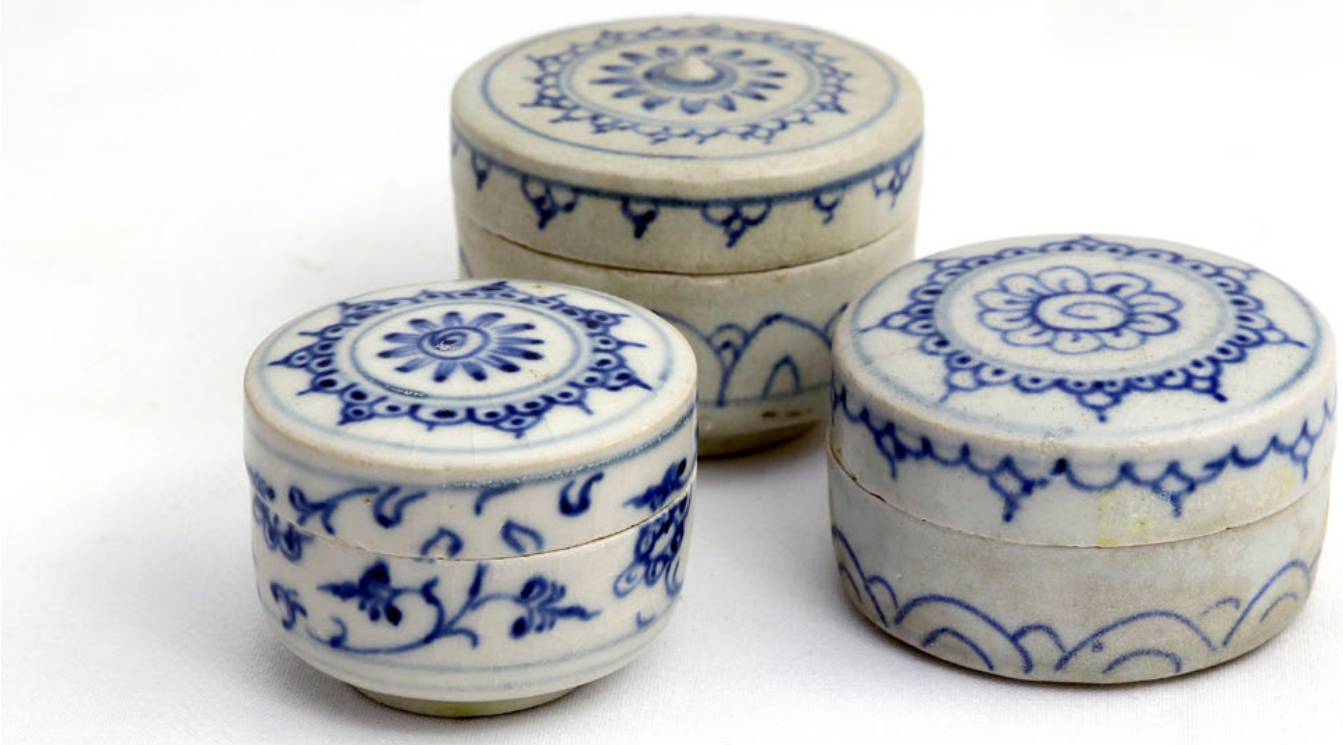

Fig. 5 Group of round boxes decorated with floral patterns, on displaying at MHiHCMC. Photo: Phạm Ngọc Uyên

The mentioned ideas may explain why blue-and-white covered boxes were created in circle and square shapes, all of which were probably exported to satisfy the Malay world.

The group of decorative boxes with a bird and sun motifs, in which the two major forms are called as lotus bud form and pear shape (Figures 6a-b). Each has an average diameter $5.7 \mathrm{~cm}$ decorated with a ring of stylized lotus petals radiating from the top; the varied main decoration is painted between two double-line bands of the upper part, including scrolling clouds, various birds, tufts of bamboo or flowering lotus, occasionally interspersed with flaming jewel. 

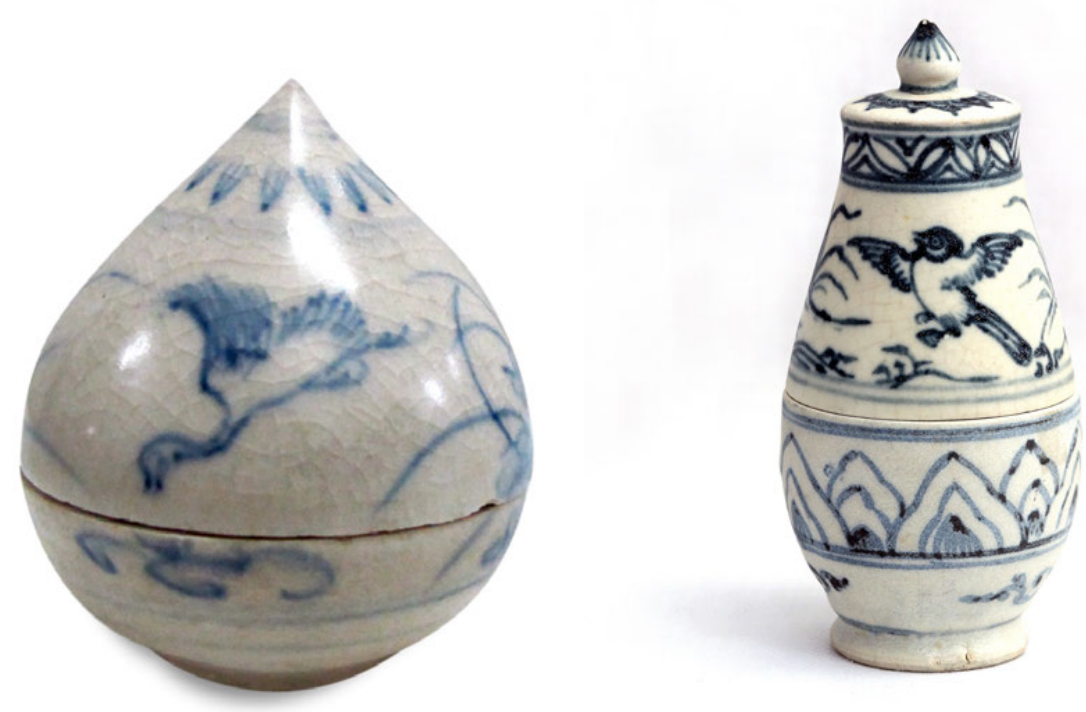

Figs. 6a,b. The group of decorative boxes with a bird and sun motifs, on display at MHiHCMC. Photo 6a: Phạm Ngọc Uyên. Photo 6b: Courtesy of MHiHCMC.

Similar to the decoration in blue against the creamy ground, each box is pear-shaped, averaging $8.5 \mathrm{~cm}$ in height, with a lotus bud-shaped knob on each lid surrounded by a band of blue petals. A magpie-like bird is depicted together with grasses/tree patterns around the top of its box; meanwhile, a simple petal-shaped band is supported on a single line close to the bottom.

One of the most fascinating aspects of Vietnamese culture is the prevalence of legends regarding the Lạc bird, known as Chim Lạc in Vietnamese; it is a sacred bird of Vietnamese depicted on bronze drums in the Đông Sơn culture, a landmark of the Vietnamese bronze age (Trần Lâm Biền, Trịnh Sinh 2017: 74-77). However, this mysterious bird stands out with its outstretched wings and a long beak; such features are distinct from the bird on the blue-and-white boxes above (Figure 5b).

Barretto-Tesoro (2020: 1-3, fig. 2) argues that ceramics would be turned into items of wealth and ritual objects once they reached the Philippines, and the local cosmology plays a major role in the decision to select foreign ceramics. In details, indigenous cosmology has structured the universe into three levels including the Kaitaasan is literally the zenith or vertex, interpreted to be the Upperworld; Lupa is Middleworld or ground; and, Kailaliman is the abyss or Underworld; each level corresponds to its own symbols. In which, sun and bird symbol for the Kaitaasan, snakes and other reptiles symbol for the Kailaliman; 
while Lupa is represented by a tall tree whose roots and branches connect Kailaliman and Kaitaasan (ibid.).

The solar motif is the first example, in which the lotus-like petals are painted around the mouth rims and bases to represent rayed-circles if pots are view from the top, the mouth and base functioned as the central of the box; the rays are sometime represented with chrysanthemums motif; those items are also noted that they were mostly found in burial sites; the oldest sunburst designs on pots found at Lemery and Batangas dating to 1810 to 1760 BP (Barretto-Tesoro 2020: 7, 13, 18; fig. 4, 9). In terms of the bird motif was commonly depicted on blue-and-white wares due to the enameled color in such products; moreover, the oldest bird motif was found in the archaeological site in Manunggul Cave in Palawan dating to $890 \mathrm{BC}$ to $710 \mathrm{BC}$ (Barretto-Tesoro 2020: 13, 17).

Notably, a general survey of ceramics found in the Philippines indicate that jarlets were common in the main island of Luzon, while large vessels and dishes were noted in large numbers in northern Mindanao; Barretto-Tesoro (2020: 18) also suggests that the use of imported products with motifs corresponding to indigenous beliefs can be a way to affirm the social position of the ruling class in the Philippines, and those who influenced foreign trade activities in the $14^{\text {th }}-16^{\text {th }}$ centuries.

It should be reminded that the Ming emperor banned overseas trade for reason still not entirely clear to historians in the late $14^{\text {th }}$ century, which called as "Ming Gap" (Brown 2009), this policy provided export opportunities for ceramic products from Việt Nam and Thailand as well.

The above blue-and-white covered boxes can be considered as typical products for Việt Nam's maritime trade in the $14^{\text {th }}-16^{\text {th }}$ centuries. The decorative ideas on each item can reveal the cultural ties and commercial connections among the ancient states in Southeast Asia, such as 'lion' image, crab, bird, elephant, and so on; the iconography of those figures have not yet been accounted for in Vietnamese folk beliefs. This can also prove that a vast consumer market of Việt Nam has been formed at that time.

\section{Conclusion}

This article has introduced the collection of blue-and-white covered boxes, belonging to the group of artifacts recovered from ancient shipwrecks on Việt Nam's coasts, being stored at the MHiHCMC. The outstanding groups of blue-and-white reflect a possible close connection to the indigenous beliefs of the archipelagic nations in ancient Southeast 
Asia, whose details can serve as criteria for analyzing consumer segments, and the consumption markets in those places. The hidden issues in these objects await to be explored may depend on surviving ethnographic data collected in the local communities in insular Southeast Asia.

\section{References}

Báo cáo khai quật khảo cổ học dưới nước tàu đắm cổ Cù Lao Chàm (Quảng Nam) 1997-1999. [Report on underwater archaeology and archaeological excavations in Cham Island in 1997-1999]. Archives of the Vietnam National Museum of History in Hà Nội.

Barretto-Tesoro, G (2020) A local discourse on the early belief system from the Philippines using evidence from the Guthe Collection. SPAFA Journal, 6 Berzacier, L (1955) L'art vietnamien. Paris: Éd. de l'Union Française.

Brown, RM (2009) The Ming Gap and Shipwreck Ceramics in Southeast Asia: Towards a Chronology of Thai Trade Ware. Bangkok: River Books.

Eugenio, LD (1985) Philippine Folktales: An Introduction. Asian Folklore Studies, 44(2): 155-177.

Gil, A (1973) Mayyang and the Crab: A Cinderella variant. Philippine Quarterly of Culture and Society, 1(1): 26-32.

Guy, J (2005) The Hoi An (Cu Lao Cham) Shipwreck Cargo and Asian Ceramic Trade.

In: G Li and CK Wan (eds.) Proceedings of the International Conference:

Chinese Export Ceramics and Maritime trade 12th -15th centuries. Hong Kong: Zhonghua shu ju, 105-125.

Hall, RK (1985) Maritime Trade and State Development in Fourteenth-Century Java.

Maritime Trade and State Development in Early Southeast Asia. Honolulu:

University of Hawai'i Press.

Han, J (2019) The Study of Thai Elephant Culture Based on the «Elephant Metaphors» in Thai Idioms. Comparative Literature: East \& West, 3(2): 148-162.

Lý, LT and Huỳnh, NT (eds.) (1996) 800 mẫu hoa văn đồ cổ Trung Quốc. [800 decorative patterns on Chinese antiques]. Hà Nội: Mỹ thuật Publisher.

Dupoizat, M-F (2013) Vietnamese Ceramics in the Malay World. Archipel, 85: 105-115. Nicolas, A (2017) Musical Terms in Malay Classical Literature: The Early Period $\left(14^{\text {th }}-17^{\text {th }}\right.$ Century). Nalanda-Sriwijaya Centre Working Paper, 24: 1-51.

Njoto, H (2018) Mythical Feline Figures in Java's Early Islamisation Period (Fifteenth to the Early Seventeenth Centuries): Sinitic and Vietnamese Imprints in Pasisir Art. Arts Asiatiques, 73: 41-60. 
Rooney, D (2008) Ancient Khmer Elephant-Jar Reflects Potters' Brilliance. SPAFA Journal, 18(3): 5-14.

Shaw, JC (1982) A comment on the Vietnamese - Thai Connection. Southeast Asian Ceramic Society (Vietnamese ceramics). Singapore: Tien Wah Press Pte Ltd, 25-27.

Silah, S, Basaree, RO, Isa, B and Redzuan, RS (2013) Tradition and transformation:

The structure of Malay woodcarving motifs in craft education. Procedia - Social and Behavioral Sciences, 90: 8

Trần, LB and Trịnh, S (2017) Thế giới biểu tượng trong di sản văn hóa [The symbolic world in the cultural Heritage]. Hà Nội: Hồng Đức Publisher.23-831.

Wagner, BA (1979/80) Stylistic Evidence for Redating of Sawankhalok Painted Covered Boxes. Oriental Art, 25(4).

Wan Norasikin Wan Ismail, Abdul Latif Samian and Nazri Muslim (2016) The Symbol of Animals in Malay Proverbs. International Journal of Humanities and Social Science Invention, 6(3): 148-154.

Ysaguirre, J, Silverman, C and Paffrath, S (2000) Treasures from the Hoi An Hoard: Important Vietnamese ceramics, Vol. 2. San Francisco: Butterfields. 